\title{
Effects of multi-walled carbon nanotubes (MWCNT) under Neisseria meningitidis transformation process
}

\author{
Ives B Mattos ${ }^{1}$, Danilo A Alves ${ }^{1}$, Luciana M Hollanda' ${ }^{1}$, Helder J Ceragiogli², Vitor Baranauskas² and \\ Marcelo Lancellotti ${ }^{{ }^{*}}$
}

\begin{abstract}
Background: This study aimed at verifying the action of multi-walled carbon nanotubes (MWCNT) under the naturally transformable Neisseria meningitidis against two different DNA obtained from isogenic mutants of this microorganism, an important pathogen implicated in the genetic horizontal transfer of DNA, causing the escape of the principal vaccination measured worldwide by the capsular switching process.

Materials and methods: The bacterium receptor strain C2135 was cultivated and had its mutant DNA donor M2 and M6, which received a receptor strain and MWCNT at three different concentrations. The inhibition effect of DNAse on the DNA in contact with nanoparticles was evaluated.

Results: The results indicated an in increase in the transformation capacity of $N$. meninigtidis in different concentrations of MWCNT when compared with negative control without nanotubes. A final analysis of the interaction between DNA and MWCNT was carried out using Raman Spectroscopy.

Conclusion: These increases in the transformation capacity mediated by MWCNT, in meningococci, indicate the interaction of these particles with the virulence acquisition of these bacteria, as well as with the increase in the vaccination escape process.
\end{abstract}

\section{Introduction}

Neisseria meningitidis is a commensal bacterium of the human upper respiratory tract that may occasionally provoke invasive infections such as septicemia and meningitis. It is also naturally competent and therefore can exchange genetic information with each other by this process. This natural competence has been directly correlated to pilliation of these organisms, as well as a specific uptake sequence, within the genome of these bacterium [1].

The use of mutations for the study of the capsular polysaccharide of $N$. meningitidis is the aim of several studies of the meningococci pathogenesis [2-4]. The capsular polysaccharide is the major virulence factor and a protective antigen. Meningococcal strains are

\footnotetext{
* Correspondence: mlancell@unicamp.br

'LABIOTEC - Biotechnology Laboratory, Department of Biochemistry, Institute of Biology CP6109, University of Campinas - UNICAMP 13083-970, Campinas, SP, Brazil

Full list of author information is available at the end of the article
}

classified into 12 different serogroups according to their capsular immune specificity, along with serogroups A, B, $\mathrm{C}, \mathrm{Y}$ and W135 are the most frequently found in invasive infections. The capsule of serogroups $B, C, Y$ and W135 strains is composed of either homopolymers (B and $\mathrm{C}$ ) or heteropolymers ( $\mathrm{Y}$ and W135) of sialic acidcontaining polysaccharides that are specifically linked, depending on the serogroup $[5,6]$. This polymerization is mediated by the polysialyltransferase, encoded by the siaD gene in strains of serogroups B and C (also called synD and synE, respectively) and by syn $G$ in serogroup W135. Capsule switching after replacement of $\operatorname{syn} E$, in a serogroup $C$ strain, by $\operatorname{syn} G$ may result from the conversion of capsule genes by transformation and allelic recombination [7-10]. Such capsule switching from serogroup C to B $N$. meningitidis was observed in several countries, either spontaneously or after vaccination campaigns [7-13]. It might explain the emergence and the clonal expansion of strains of serogroup W135 of 
$N$. meningitidis in the year 2000 among Hajj pilgrims who had been vaccinated against meningococci of serogroups A and C [14]. These W135 strains belong to the same clonal complex ET-37/ST-11 as prominent serogroup $C$ strains involved in outbreaks worldwide $[8,9,15]$. Hence, the emergence of these W135 strains in epidemic conditions raised the question about a possible capsule switching as an escape mechanism to vaccineinduced immunity. Also, these events are expected to occur continuously and can be selected by immune response against a particular capsular polysaccharide [9].

However, the interference of immune response with transformation efficacy has not been yet evaluated. Specific capsular antibodies are expected to bind to the bacterial surface and hence they interfere in DNA recognition and uptake. Also, environmental interference under the transformation process of this bacterium is unknown.

This work aimed at the use of multi-walled carbon nanotubes (MWCNT) for the study of the nanostructures action on the transformation process of meningococci, specifically their functions under the capsular switching process. The methods used in this work aimed at the action of MWCNT in the transformation of serogroup C $N$. meningitidis against two different DNA obtained from isogenic mutants of this microorganism.

\section{Methods}

Synthesis of multi-walled carbon nanotubes

The carbon nanotubes were produced by the process of hot filament chemical vapor deposition (HFCVD), at the Nanoengineering and Diamond Laboratory (NanoEng) of the Department of Semiconductors, Instruments and Photonics of the UNICAMP School of Electric Engineering and Computer Science. The carbon nanotubes were made in a copper substrate covered by a conductive polymer film called polyaniline. The polyaniline film covering the copper was dried on a hot plate at $100^{\circ} \mathrm{C}$. After that, $0.2 \mathrm{ml}$ of a $2 \mathrm{~g} / \mathrm{l}$ acetone-diluted nickel nitrate $\left(\mathrm{Ni}\left(\mathrm{NO}_{3}\right)_{2}\right)$ (where the nickel is the catalyzer for the growth of carbon nanotubes) was dropped on the dry polyaniline film. After drying, in room temperature, the polyaniline film was introduced into the HFCVD reactor in nitrogen atmosphere at $450^{\circ} \mathrm{C}$ and $27 \mathrm{mbar}$ pressure for 30 minutes of growth time. An acetone solution of camphor bubbled in hydrogen gas was used as source of carbon. Morphological analyses were made by FESEM (Field Emission Scanning Electron Microscopy) using a JEOL JSM-6330F operated at $5 \mathrm{KV}, 8 \mu \mathrm{A}$, and HRTEM (High Resolution Transmission Electron Microscopy) using a JEOL JSM 3010 operated at 300 $\mathrm{KV}$ and $73 \mu \mathrm{A}$. Figure 1 shows typical images of FESEM and HRTEM. We also used other nanostructures to confirm our results as the NC nanotubes (commercially obtained from Helix Material Solutions, USA), the NT2 were described by Grecco et al. [16].

\section{Bacterial Strains and Media}

The characteristics of the strains used in this study are described in Table 1 . They were grown at $37^{\circ} \mathrm{C}$ under $5 \%$ of $\mathrm{CO}_{2}$ on GCB agar medium (Difco) containing the supplements described by Lancellotti et al. [9]. When needed, culture media were supplemented with erythromycin at 2 $\mu \mathrm{g} / \mathrm{ml}$ and spectomycin at $40 \mu \mathrm{g} / \mathrm{ml}$. Escherichia coli strains used for plasmid preparations were DH5 $\alpha$ [17].

\section{DNA Techniques}

Recombinant DNA protocols and transformation were performed as described previously [18]. The oligonucleotides used are listed in Table 2. All the mutants

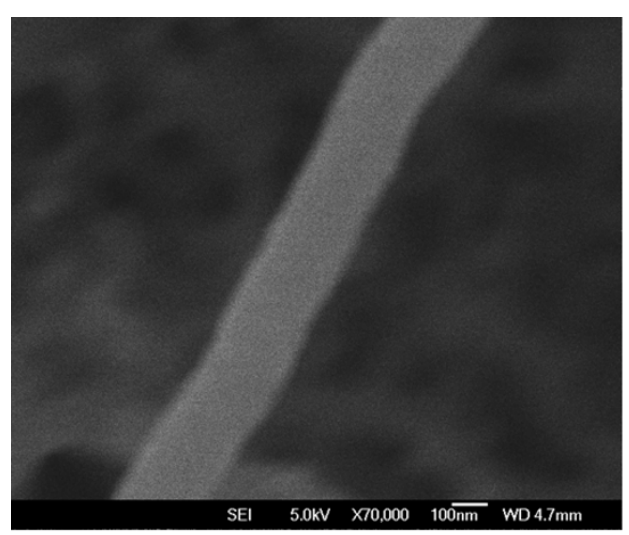

a

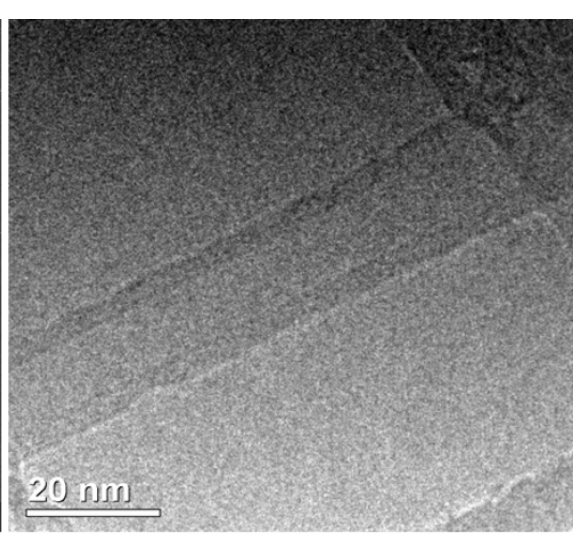

b

Figure 1 shows (a) the morphologic by SEM and (b) structure by HRTEM of typical as deposited MWCNTs. Scale bars are indicated, the outer diameter is ca. $200 \mathrm{~nm}$ and length > $1500 \mathrm{~nm}$ for the MWCNT show in (a). Multi-walled structures are presented in (b) corresponding to a MWCNT with outer diameter of ca. $20 \mathrm{~nm}$. 
Table 1 Bacterial Strains used in this work

\begin{tabular}{|c|c|c|}
\hline Strain & Characteristics & Origin (Reference) \\
\hline$\overline{\mathrm{DH} 5} \propto$ & Escherichia coli F-, endA1, hsdR17 c, supE44, thi-1, gir A96, relA1 & [17] \\
\hline pLAN45 & 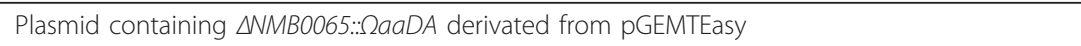 & [18] \\
\hline pLAN13 & Plasmid containing the fusion of synG::ermAM & [18] \\
\hline $\mathrm{C} 2135$ & Neisseria meningitidis serogroup C, BIOMERIEUX & INCQS - FIOCRUZ \\
\hline W135ATCC & Neisseria meningitidis serogroup W135, ATCC35559 & INCQS - FIOCRUZ \\
\hline M2 & N.meningitidis isogenic mutant $\triangle \mathrm{NMB0065:: \Omega aaDA}$ & [18] \\
\hline M6 & N.meningitidis W135ATCC transformed with pLAN13 to generate a fusioned strain synG:ermAM & [18] \\
\hline
\end{tabular}

obtained by homologous recombination were checked by Polymerization Chain Reaction - PCR analysis using an oligonucleotide harboring the target gene and another harboring the cassette.

\section{Construction of NMB0065 mutant by polar mutation}

This mutant construction follows the specifications described by Hollanda et al. [18]. Briefly, the NMB0065 sequence from $N$. meningitidis $\mathrm{C} 2135$ was amplified using 03.12-3 and 03.12-4 oligonucleotides (table 2). This fragment was cloned into the pGEM-T Easy Vector System II (Promega Corporation, Madison, WI, USA), to generate the plasmid pLAN6. E. coli strain Z501 was transformed with plasmid pLAN6 resulting in the plasmid pLAN7. The $\Omega a a D A$ cassette was inserted into the BclI site of pLAN7 to generate plasmid pLAN45, which was transformed into the $\mathrm{C} 2135$ strain, generating the mutant strain M2 (Figure 2).

\section{Construction of serogroup W135 mutants in transcriptional fusion synG::ermAM}

As the mutant M2, this mutant construction follows the specifications described in Hollanda et al. [18]. Briefly, the $\operatorname{syn} G$ gene responsible for the synthesis of the W135 capsule was amplified using the 98-30 and 03-12-5 oligonucleotides (table 2) from the serogroup W135 strain
W135ATCC. The amplified fragment was cloned into the pGEM-T Easy Vector System I (Promega, Madison, WI, USA), to generate the plasmid pLAN11 (Figure 3). Another fragment was amplified using the 04-02-2/ galECK29A from $\operatorname{syn} G$ downstream sequence, cloned into pGEM-T Easy Vector, to generate pLAN52. The ermAM cassette was amplified by ERAM1/ERAM3 and inserted into NcoI site of pLAN52 to generate pLAN53. The fragment amplified from pLAN53 with the ERAM1 and galECK29A [19] was inserted into PstI site of pLAN11 to generate pLAN13-2. This plasmid was linearised by the enzyme SphI and transformed into W135 $5_{\text {ATCC }}$ strain to generate the synG::ermAM fusioned strain M6, erythromycin resistant.

\section{Analysis of transformation frequency up to MWCNT contact}

At $1.10^{8}$ colony-forming units - CFU - of the receptor strain C2135, we added $1 \mu$ g genomic DNA from M2 and M6 mutants and 10, 20 and $50 \mu \mathrm{g}$ of different MWCNT. A negative control was also performed without MWCNT. The suspension was incubated for three hours at $37^{\circ} \mathrm{C}$ in atmosphere of $5 \%$ of $\mathrm{CO}_{2}$ by three hours. The counts of total CFU were performed in GCB spectinomycin or erythromycin plates in triplicate analysis (for M2 and M6 isogenic mutants, respectively). The

Table 2 Oligonucleotides used in this work

\begin{tabular}{|c|c|c|}
\hline Oligonucleotide & Sequence $5^{\prime}-3^{\prime}$ & Description \\
\hline $03.12-3$ & TGCGGATCCGCAGTAATITATCGGTTGG & NMB0065 forward \\
\hline $03.12-4$ & CCCCACTACCTAAAAAATGCTGATTTG & NMB0065 reverse \\
\hline aadA1 & TGCCGTCACGCAACTGGTCCA & ऽaaDA forward \\
\hline aadA2 & CAACTGATCTGCGCGCGAGGC & $\Omega a a D A$ reverse \\
\hline 98.30 & GGTGAATCTTCCGAGCAGGAAA & synG forward \\
\hline 98.31 & AAAGCTGCGCGGAAGAATAGTG & synG reverse \\
\hline $03.12-5^{*}$ & TCGGGATCCTTATIITCTTGGCCAAAAA & synG reverse \\
\hline $04.02-1$ & CAATGAATCTCGCGTTGCTGTAGGTG & synG forward \\
\hline $04.02-2$ & GAAAAATAATTTGGGGCTTAGG & synG forward \\
\hline galECK29A & CTTCCATCATTTGTGCAAGGCTGC & galE reverse \\
\hline ERAM1 & GCAAACTTAAGAGTGTGTTGATAG & ermAM forward \\
\hline ERAM3 & AAGCTTGCCGTCTGAATGGGACCTCTITA GCTTCTTGG & ermAM reverse \\
\hline
\end{tabular}

*The underlined sequences in italic are the insertion of the BamHI site into original sequence 


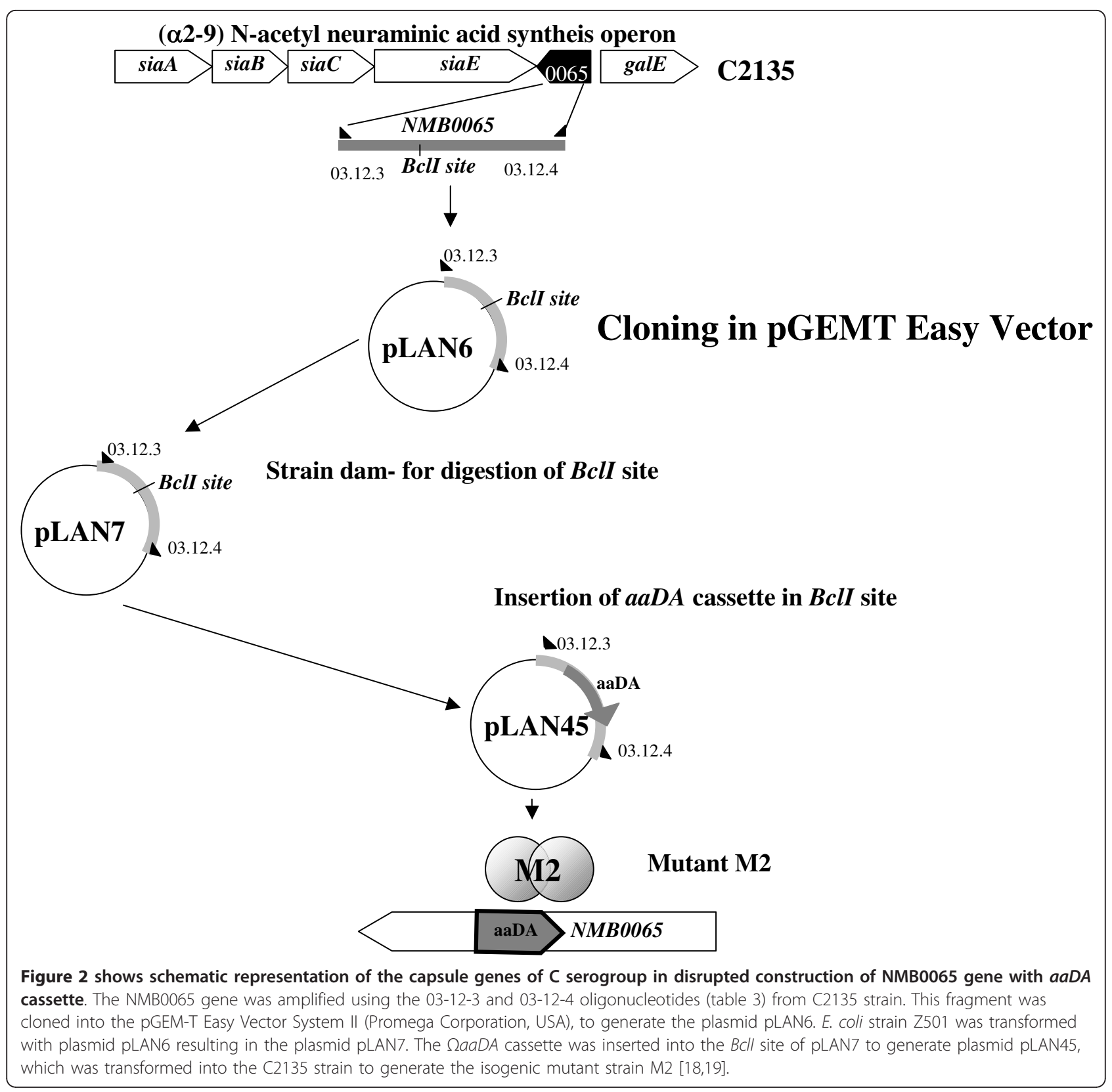

CFU obtained in plates containing specific antibiotic were analyzed by PCR for the presence of target gene transfer in the transforming units ( $\Omega a a D A$ cassette for the M2 DNA and synG for M6 donor DNA). In order to verify the interaction between DNA, MWCNT and DNAse action, the same amounts of DNA $(1 \mu \mathrm{g})$ from M2 and M6 mutants, MWCNT (20 $\mu \mathrm{g})$ and bacterial cells were submitted to action $5 \mathrm{U}$ of DNase (New England Biolabs, UK) and further transformation process. Also, the counts of cfu were performed in GCB spectinomycin or erythromycin plates in triplicate analysis (for M2 and M6 isogenic mutants respectively).
Analysis of interaction between DNA and MWCNT by Raman spectroscopy

The prior analysis of DNA from M2 and M6 mutant strains with MWCNT was performed under a mix of 1 $\mu \mathrm{g}$ of M6 genomic DNA and $20 \mu \mathrm{g}$ of MWCNT. The samples were characterized by Raman spectroscopy $[20,21]$. The spectra were recorded at room temperature using a Renishaw microprobe in Via system, employing an UV laser for excitation $(\lambda=325 \mathrm{~nm})$ at about $10 \mathrm{~mW}$. The samples M2 and M6 were dripped onto a quartz substrate for UV laser Raman spectroscopy. 


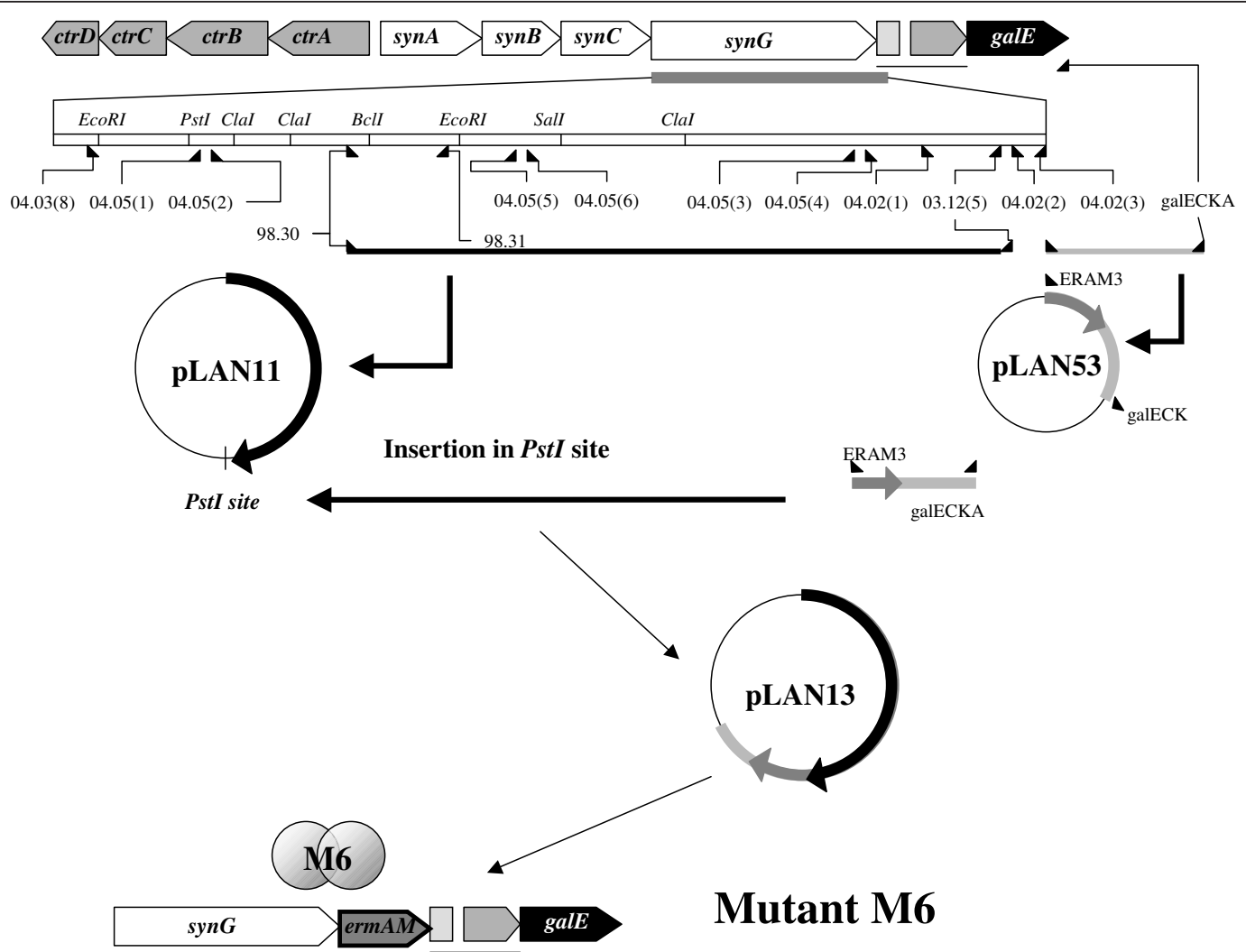

Figure 3 Schematic representation of the capsule genes of W135 serogroup in transcriptional fusion of synG with ermAM cassette. The synG gene responsible for the synthesis of the W135 capsule was amplified using the 98-30 and 03-12-5 oligonucleotides (table 2) from W135 ATCC Strain. The amplified fragment was cloned into the PGEM-T Easy Vector System I (Promega, Madison, WI, USA), to generate the plasmid pLAN11. In the same conditions, another fragment was amplified using the 04.02-2/galECK29A from synG downstream sequence to generate pLAN52. The ermAM cassette was inserted into Ncol site of pLAN52 to generate pLAN53. The fragment amplified from pLAN53 with the ERAM1 and galECK29A [19] was inserted into Pstl site of pLAN11 to generate pLAN13-2. This plasmid was linearised by the enzyme Sphl and transformed into W135 ATcc strain to generate the synG.:ermAM strain M6, erythromycin resistant [18].

\section{Results and discussion}

The effects of the MWCNT were verified by an increase in the number of CFU obtained from many transformation processes. The CFU number resulting from the transformation process using DNA from M2 donor strain was higher than the one obtained using M6 as the donor strain. Also, the use of three different MWCNT and three different concentrations (10, 20 and $50 \mu \mathrm{g}$ of each MWCNT) showed an increase in the number of CFU resulted from the transformation process using both DNA donor strains (Figure $4(\mathrm{c}-\mathrm{d})$ and table 3).

The intention of two different DNA donors was to certificate the independence of MWCNT action under the same bacterial strain - N. meningitidis C2135. Further analysis by PCR demonstrated the transfer of the tagged gene from M2 and M6 in transformed strains (data not shown). The Raman analysis showed the interaction of MWCNT with the DNA obtained from M6 mutant strains as viewed in Figure 4(a-b).
Data analyses were made by ratio values between the numbers of transformants cfu obtained with MWCNT by median values of transformants cfu obtained without nanotubes treatment (Figures $4 \mathrm{c}-\mathrm{d}$ and table 3 ). The values were analyzed by one-way analysis of variance ANOVA (Tukey's test compared each treatment to control without nanoparticles in transformation, considering significant values of $\mathrm{P}>0.05)$. Some values obtained with commercial MWCNT - NC and NT2 showed different results when compared with NT1 (table 3 and Figure 4).

The relations between the meningococci transformation and MWCNT action viewed in these results could mimic the presence of carbon nanoparticles in atmosphere and evoke the emergence of outbreaks of Brazilian purpuric fever (BPF) caused by another naturally competent bacteria, Haemophilus influenzae biogroup aegyptius [22,23]. The Haemophilus influenzae biotype aegyptius causes $\mathrm{BPF}$, a dangerous inflammatory disease known as purpura fulminans with a great mortality rate 


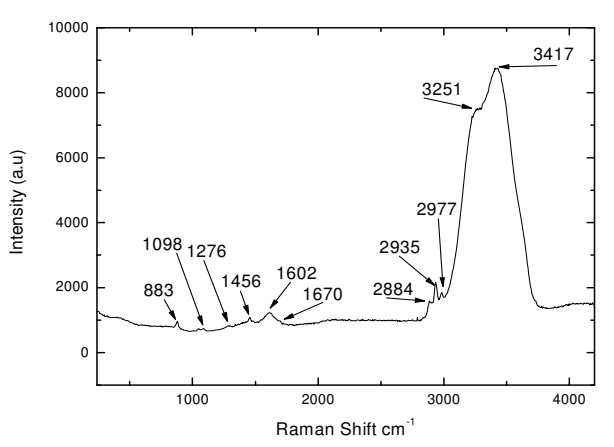

a

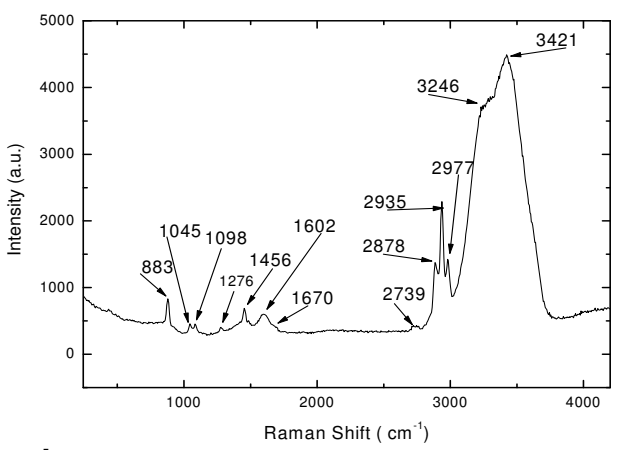

b

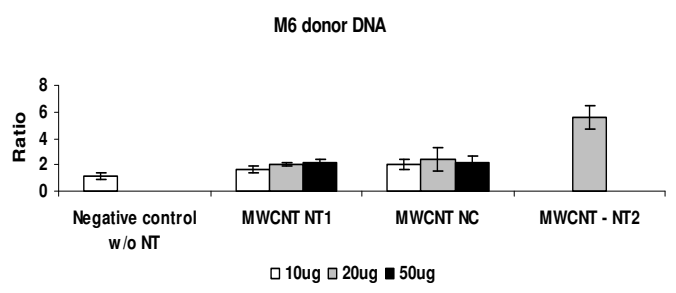

d

Figure 4 shows signal of DNA in the region until $2000 \mathrm{~cm}^{-1}$. DNA consist of three groups: phosphates, deoxyribose and four bases such as A (adenine), T (thymine), C (cytosine) and G (guanine). In our work, the bands could be assigned to 883/1098/1045 $\mathrm{cm}^{-1}$ - O-P-O backbone; $1276 \mathrm{~cm}^{-1}$ - C (cytosine); $1456 \mathrm{~cm}^{-1}$ - A (adenine);1602 $\mathrm{cm}^{-1}$ - guanine (G) and $1670 \mathrm{~cm}^{-}-\mathrm{T}$ (thymine). The bands of DNA donor M2 (a) and M6 (b) are in accordance with some authors $[21,22]$. The bands $2739-3421 \mathrm{~cm}^{-1}$ are not assigned to DNA, it is assigned to the quartz substrate. In (c) and (d) it shows the action of the MWCNT under Neisseria meningitidis strain C2135 using as donor DNA the M2 (c) and M6 (d).

Table 3 Values obtained from C21 35 transformation using the donor DNA from M2 and M6 mutants.

\begin{tabular}{|c|c|c|}
\hline Donor DNA $(1 \mu \mathrm{g})$ & $\begin{array}{l}\text { Ratio (means obtained exposed to MWCNT/mean of negative } \\
\text { control) }\end{array}$ & $P$ values (one way Tukey's test) \\
\hline Negative Control (without MWCNT) M2 & $1.02 \pm 0.17$ & \\
\hline NT1 $(10 \mu \mathrm{g})$ & $0.89 \pm 0.09$ & $P=0,1631$ (non significant) \\
\hline NT1 $(20 \mu \mathrm{g})$ & $2.24 \pm 0.70$ & $P<0,05(P=0,0496$ significant $)$ \\
\hline NT1 $(50 \mu g)$ & $3.52 \pm 0.50$ & $\begin{array}{c}P<0,05(P=0,0073 \text { very } \\
\text { significant })\end{array}$ \\
\hline NC $(10 \mu g)$ & $0.85 \pm 0.50$ & $P=0,3166$ (non significant) \\
\hline NC $(20 \mu \mathrm{g})$ & $2.18 \pm 0.90$ & $P=0,0798$ (non significant) \\
\hline NC $(50 \mu \mathrm{g})$ & $4.36 \pm 1.18$ & $P<0,05(P<0,0020$ significant $)$ \\
\hline NT2 $(20 \mu \mathrm{g})$ & $1.42 \pm 0.13$ & $P<0,05(P=0,0240$ significant $)$ \\
\hline $\begin{array}{l}\text { Negative Control (without mesoporous } \\
\text { silim6 }\end{array}$ & $1.09 \pm 0.25$ & \\
\hline NT1 $(10 \mu \mathrm{g})$ & $1.71 \pm 0.25$ & $P<0,05(P=0,0385$ significant $)$ \\
\hline NT1 $(20 \mu g)$ & $2.03 \pm 0.08$ & $\begin{array}{c}P<0,05(P=0,0034 \text { very } \\
\text { significant })\end{array}$ \\
\hline NT1 $(50 \mu \mathrm{g})$ & $2.11 \pm 0.30$ & $P<0,05(P=0,0106$ significant $)$ \\
\hline NC $(10 \mu g)$ & $2.03 \pm 0.35$ & $P<0,05(P=0,0193$ significant $)$ \\
\hline NC $(20 \mu \mathrm{g})$ & $2.44 \pm 0.88$ & $P<0,05(P=0,0490$ significant $)$ \\
\hline NC $(50 \mu g)$ & $2.14 \pm 0.49$ & $P<0,05(P=0,0403$ significant $)$ \\
\hline NT2 $(20 \mu \mathrm{g})$ & $5.58 \pm 0.86$ & $\begin{array}{c}P<0,05(P=0,0065 \text { very } \\
\text { significant })\end{array}$ \\
\hline
\end{tabular}


[24]. Kroll et al. [24] described these Haemophilus influenzae strains, usually associated with conjunctivitis cases, as a product of horizontal transfer between $N$. meningitidis and Haemophilus influenzae. In the same geographic region of these outbreaks, the primitive agricultural practice, performed by burning sugar cane, generates an emission of carbon micro and nanoparticles in the atmosphere, potentially provoking respiratory disorders by particles inhalation [25]. Our group has been studying these bacteria and testing them with MWCNT on its transformation process.

This process is similar to the phenomena of capsular switching as described in sub Saharan African [26-28] and Saudi Arabian regions (Hajj pilgrimage) [26,29-35]. In desert zones, the ramarthan wind and the presence of silica nanostructures facilitates the capsular switching process in meningococci strains [26,29-36]. Thus, new experiments using animal models that could confirm this hypothesis have been performed by our group. Also, the increases in the transformation capacity in bacteria have been verified in Escherichia coli by nanotube structures, as described by Rojas-Chapana et al. [37].

The results of DNAse inhibition over free DNA (Figure 5) could explain the protection of the bacterial genes by MWCNT contact in this nanostructure. This evidence is showed in the graphic of Figure 5 with the increase of CFU in the test containing DNAse-treated DNA and exposed to $20 \mu \mathrm{g}$ of MWCNT. These results need further experiments in order to better understand this interaction between bacterial compounds and the transformation system (represented in Figure 5). Furthermore, animal models, for these studies, may be very interesting for future assessments of atmospheric contamination by carbon nanoparticles produced by primitive agriculture and carbon miners.

This work indicated, for the first time in scientific literature, that the action of atmospheric nanoparticles obtained from anthropic activities, such as primitive agriculture, influences the bacterial transformation process.

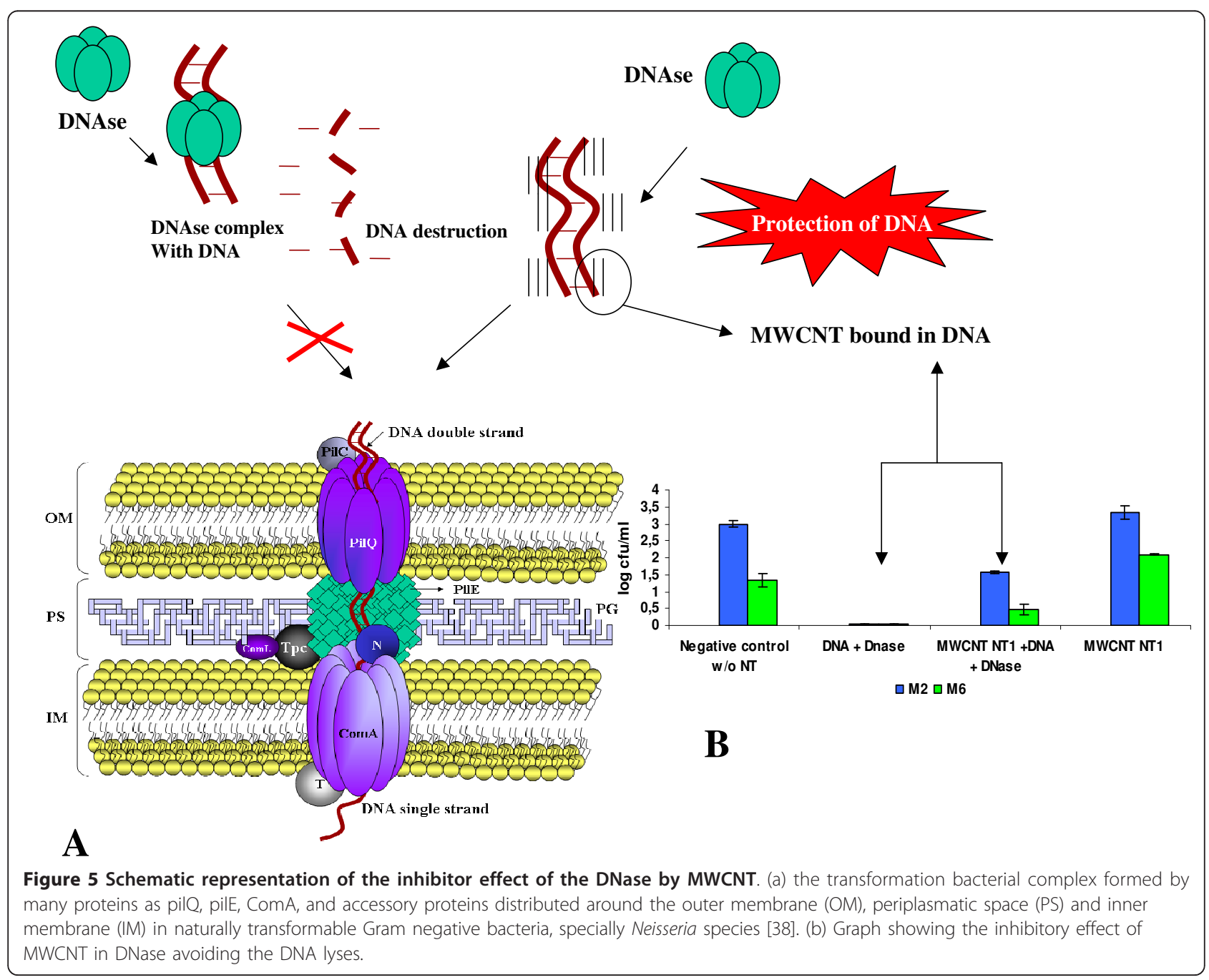




\section{Conclusion}

The increase in the transformation capacity mediated by MWCNT in meningococci indicates an interaction of these particles with the bacterial DNA leading to virulence acquisition and an increase in the escape to vaccination. The presence of these nanoparticles protects the DNA from DNAse action, increasing the recombination frequency. These results show that important measures for public health, in places where the MWCNT or carbon microparticles are produced, need to be carefully revised.

\section{Acknowledgements}

This study has been financed by CAPES, FAPESP and CNPq. These supports helped us to supply reagent and equipments for the entire research development. FAPESP (number 2008/56777-5) and CNPq (number 575313/ 2008-0) supported the Laboratory of Biotechnology (Coordinated by M.L.). CAPES supported NanoEng (Coordinated by VB, Nanobiotechnology Program - Effects of carbon nanotubes under biological systems) and the personal fellowships for LMH, HJC. Thanks for the English revision to Júlia N. Varela and Maria Cecília T. Amstalden.

\section{Author details}

'LABIOTEC - Biotechnology Laboratory, Department of Biochemistry, Institute of Biology CP6109, University of Campinas - UNICAMP 13083-970, Campinas, SP, Brazil. ${ }^{2}$ NanoEng - NanoEngineering and Diamond Laboratory, School of Electrical and Computer Engineering, Department of Semiconductors, Instruments and Photonics, University of Campinas, UNICAMP, Av. Albert Einstein N.400, CEP 13 083-852 Campinas, São Paulo, Brasil.

\section{Authors' contributions}

IBM carried out the Molecular Biology design and plasmids; DAA carried out the molecular microbiologic tests; LMH carried out the molecular genetics studies; HJC carried out the MWCNT synthesis and FESEM, HRTEM and Raman tests; VB participated in the drafting of the manuscript and gave technical support in Nanoengineering; ML carried out the molecular genetics studies and also the draft of the manuscript. All the authors read and approved the final manuscript.

\section{Competing interests}

The authors declare that they have no competing interests.

Received: 24 March 2011 Accepted: 16 November 2011 Published: 16 November 2011

\section{References}

1. Tonjum T, Koomey M: The pilus colonization factor of pathogenic neisserial species: organelle biogenesis and structure/function relationships-a review. Gene 1997, 192:155-163.

2. Alonso JM, Guiyoule A, Zarantonelli ML, Ramisse F, Pires R, Antignac A, Deghmane AE, Huerre M, van der Werf S, Taha MK: A model of meningococcal bacteremia after respiratory superinfection in influenza A virus-infected mice. FEMS Microbiol Lett 2003, 222:99-106.

3. Nassif $X$, So M: Interaction of pathogenic neisseriae with nonphagocytic cells. Clin Microbiol Rev 1995, 8:376-388.

4. Spinosa MR, Progida C, Tala A, Cogli L, Alifano P, Bucci C: The Neisseria meningitidis capsule is important for intracellular survival in human cells. Infect Immun 2007, 75:3594-3603.

5. Frosch M, Muller D, Bousset $K$, Muller A: Conserved outer membrane protein of Neisseria meningitidis involved in capsule expression. Infect Immun 1992, 60:798-803.

6. Taha MK: Molecular detection and characterization of Neisseria meningitidis. Expert Rev Mol Diagn 2002, 2:143-150.

7. Swartley JS, Marfin AA, Edupuganti S, Liu LJ, Cieslak P, Perkins B, Wenger JD, Stephens DS: Capsule switching of Neisseria meningitidis. Proc Natl Acad Sci USA 1997, 94:271-276.
8. Zarantonelli ML, Lancellotti M, Deghmane AE, Giorgini D, Hong E, Ruckly C, Alonso JM, Taha MK: Hyperinvasive genotypes of Neisseria meningitidis in France. Clin Microbiol Infect 2008, 14:467-472.

9. Lancellotti M, Guiyoule A, Ruckly C, Hong E, Alonso JM, Taha MK: Conserved virulence of $C$ to $B$ capsule switched Neisseria meningitidis clinical isolates belonging to ET-37/ST-11 clonal complex. Microbes Infect 2006, 8:191-196.

10. Kriz P, Musilek M, Skoczynska A, Hryniewicz W: Genetic and antigenic characteristics of Neisseria meningitidis strains isolated in the Czech Republic in 1997-1998. Eur J Clin Microbiol Infect Dis 2000, 19:452-459.

11. Alcala B, Salcedo C, de la Fuente L, Arreaza L, Uria MJ, Abad R, Enriquez R, Vazquez JA, Motge M, de Batlle J: Neisseria meningitidis showing decreased susceptibility to ciprofloxacin: first report in Spain. $J$ Antimicrob Chemother 2004, 53:409.

12. Alcala B, Salcedo C, Arreaza L, Berron S, De La Fuente L, Vazquez JA: The epidemic wave of meningococcal disease in Spain in 1996-1997: probably a consequence of strain displacement. J Med Microbiol 2002, 51:1102-1106

13. Perez-Trallero E, Vicente D, Montes M, Cisterna R: Positive effect of meningococcal $C$ vaccination on serogroup replacement in Neisseria meningitidis. Lancet 2002, 360:953.

14. Taha MK, Bichier E, Perrocheau A, Alonso JM: Circumvention of herd immunity during an outbreak of meningococcal disease could be correlated to escape mutation in the porA gene of Neisseria meningitidis. Infect Immun 2001, 69:1971-1973.

15. Zarantonelli ML, Antignac A, Lancellotti M, Guiyoule A, Alonso JM, Taha MK: Immunogenicity of meningococcal PBP2 during natural infection and protective activity of anti-PBP2 antibodies against meningococcal bacteraemia in mice. J Antimicrob Chemother 2006, 57:924-930.

16. Grecco AC, Paula RF, Mizutani E, Sartorelli JC, Milani AM, Longhini AL, Oliveira EC, Pradella F, Silva VD, Moraes AS, et al: Up-regulation of T lymphocyte and antibody production by inflammatory cytokines released by macrophage exposure to multi-walled carbon nanotubes. Nanotechnology 22:265103.

17. Hanahan D, Meselson M: Plasmid screening at high colony density. Methods Enzymol 1983, 100:333-342.

18. Hollanda LM, Cury GC, Pereira RF, Ferreira GA, Sousa A, Sousa EM, Lancellotti M: Effect of mesoporous silica under Neisseria meningitidis transformation process: environmental effects under meningococci transformation. J Nanobiotechnology 2011, 9:28.

19. Dolan-Livengood JM, Miller YK, Martin LE, Urwin R, Stephens DS: Genetic basis for nongroupable Neisseria meningitidis. J Infect Dis 2003, 187:1616-1628.

20. Sun L, Sun Y, Xu F, Zhang Y, Yang T, Guo C, Liu Z, Li Z: Atomic force microscopy and surface-enhanced Raman scattering detection of DNA based on DNA-nanoparticle complexes. Nanotechnology 2009, 20:125502.

21. Palma BF, Ferrari $A B$, Bitar RA: DNA extraction systematics for spectroscopic studies. Sensors 2008, 9.

22. Davis J, Smith AL, Hughes WR, Golomb M: Evolution of an autotransporter: domain shuffling and lateral transfer from pathogenic Haemophilus to Neisseria. J Bacteriol 2001, 183:4626-4635.

23. Li MS, Farrant JL, Langford PR, Kroll JS: Identification and characterization of genomic loci unique to the Brazilian purpuric fever clonal group of $\mathrm{H}$. influenzae biogroup aegyptius: functionality explored using meningococcal homology. Mol Microbiol 2003, 47:1101-1111.

24. Kroll JS, Wilks KE, Farrant JL, Langford PR: Natural genetic exchange between Haemophilus and Neisseria: intergeneric transfer of chromosomal genes between major human pathogens. Proc Natl Acad Sci USA 1998, 95:12381-12385.

25. Ribeiro $\mathrm{H}$, Assunção JV: Efeitos das queimadas na saúde humana. Estudos Avançados 2002, 16:24.

26. Alonso JM, Bertherat E, Perea W, Borrow R, Chanteau S, Cohet C, Dodet B, Greenwood B, LaForce FM, Muros-Le Rouzic E, et al: From genomics to surveillance, prevention and control: new challenges for the African meningitis belt. Bull Soc Pathol Exot 2006, 99:404-408.

27. Caugant DA, Nicolas P: Molecular surveillance of meningococcal meningitis in Africa. Vaccine 2007, 25(Suppl 1):A8-11.

28. Zombre S, Hacen MM, Ouango G, Sanou S, Adamou Y, Koumare B, Konde MK: The outbreak of meningitis due to Neisseria meningitidis W135 in 2003 in Burkina Faso and the national response: main lessons learnt. Vaccine 2007, 25(Suppl 1):A69-71. 
29. Wilder-Smith A: Meningococcal vaccine in travelers. Curr Opin Infect Dis 2007, 20:454-460.

30. Wilder-Smith A, Barkham TM, Chew SK, Paton NI: Absence of Neisseria meningitidis W-135 electrophoretic Type 37 during the Hajj, 2002. Emerg Infect Dis 2003, 9:734-737.

31. Wilder-Smith A, Barkham TM, Earnest A, Paton NI: Acquisition of W135 meningococcal carriage in Hajj pilgrims and transmission to household contacts: prospective study. Bmj 2002, 325:365-366.

32. Wilder-Smith A, Barkham TM, Ravindran S, Earnest A, Paton NI: Persistence of W135 Neisseria meningitidis carriage in returning Hajj pilgrims: risk for early and late transmission to household contacts. Emerg Infect Dis 2003, 9:123-126

33. Wilder-Smith A, Goh KT, Barkham T, Paton NI: Hajj-associated outbreak strain of Neisseria meningitidis serogroup W135: estimates of the attack rate in a defined population and the risk of invasive disease developing in carriers. Clin Infect Dis 2003, 36:679-683.

34. Wilder-Smith A, Memish Z: Meningococcal disease and travel. Int J Antimicrob Agents 2003, 21:102-106.

35. Wilder-Smith A, Paton NI, Barkham TM, Earnest A: Meningococcal carriage in Umra pilgrims returning from Saudi Arabia. J Travel Med 2003, 10:147-149.

36. Wilder-Smith A: W135 meningococcal carriage in association with the Hajj pilgrimage 2001: the Singapore experience. Int J Antimicrob Agents 2003, 21:112-115.

37. Rojas-Chapana JA, Giersig M: Multi-walled carbon nanotubes and metallic nanoparticles and their application in biomedicine. J Nanosci Nanotechnol 2006, 6:316-321.

38. Dubnau D: DNA uptake in bacteria. Annu Rev Microbiol 1999, 53:217-244.

doi:10.1186/1477-3155-9-53

Cite this article as: Mattos et al: Effects of multi-walled carbon nanotubes (MWCNT) under Neisseria meningitidis transformation process. Journal of Nanobiotechnology 2011 9:53.

\section{Submit your next manuscript to BioMed Central and take full advantage of:}

- Convenient online submission

- Thorough peer review

- No space constraints or color figure charges

- Immediate publication on acceptance

- Inclusion in PubMed, CAS, Scopus and Google Scholar

- Research which is freely available for redistribution

Submit your manuscript at www.biomedcentral.com/submit
C Biomed Central 